\title{
DNA extraction method selection for agricultural soil using TOPSIS multiple criteria decision-making model
}

\author{
Sepideh Pakpour ${ }^{1}$, Snizhana V. Olishevska ${ }^{2,3}$, Shiv O. Prasher ${ }^{2}$, Abbas S. Milani ${ }^{4}$, \\ Martin R. Chénier ${ }^{3,5^{*}}$ \\ ${ }^{1}$ Department of Biology, University of British Columbia, Kelowna, Canada \\ ${ }^{2}$ Department of Bioresource Engineering, McGill University, Montreal, Canada \\ ${ }^{3}$ Department of Animal Science, McGill University, Montreal, Canada \\ ${ }^{4}$ School of Engineering, University of British Columbia, Kelowna, Canada \\ ${ }_{5}^{5}$ Department of Food Science and Agricultural Chemistry, McGill University, Montreal, Canada \\ Email: ${ }^{*}$ martin.chenier@mcgill.ca
}

Received 20 June 2013; revised 22 July 2013; accepted 15 August 2013

Copyright (C) 2013 Sepideh Pakpour et al. This is an open access article distributed under the Creative Commons Attribution License, which permits unrestricted use, distribution, and reproduction in any medium, provided the original work is properly cited.

\begin{abstract}
There is an increased interest in the extraction of nucleic acids from various environmental samples since culture-independent molecular techniques contribute to deepen and broaden the understanding of a greater portion of uncultivable microorganisms. Due to difficulties to select the optimum DNA extraction method in view of downstream molecular analyses, this article presents a straightforward mathematical framework for comparing some of the most commonly used methods. Four commercial DNA extraction kits and two physical-chemical methods (bead-beating and freeze-thaw) were compared for the extraction of DNA under several quantitative DNA analysis criteria: yield of extraction, purity of extracted DNA $\left(A_{260 / 280}\right.$ and $A_{260 / 230}$ ratios), degradation degree of DNA, easiness of PCR amplification, duration of extraction, and cost per extraction. From a practical point of view, it is unlikely that a single DNA extraction strategy can be optimum for all selected criteria. Hence, a systematic Technique for Order Preference by Similarity to Ideal Solution (TOPSIS) was employed to compare the methods. The PowerSoil ${ }^{\circledR}$ DNA Isolation Kit was systematically defined as the best performing method for extracting DNA from soil samples. More specifically, for soil:manure and soil:manure:biochar mixtures, the PowerSoil ${ }^{\circledR}$ DNA Isolation Kit method performed best, while for neat soil samples its alternative version gained the first rank.
\end{abstract}

Keywords: DNA Extraction; Agricultural Soil; Biochar; Poultry Manure; Multiple Criteria Decision-Making;

*Corresponding author.
Technique for Order Preference by Similarity to Ideal Solution

\section{INTRODUCTION}

Soil is a unique ecosystem containing many different niches and creating favourable conditions for the development of different groups of microorganisms $[1,2]$. Since less than $1 \%$ of soil microorganisms can be grown in laboratory conditions using culture media $[3,4]$ and the vast majority are not cultivable $[5,6]$, a significant number of studies dealing with microbial diversity utilize molecular tools such as competitive PCR, real-time PCR, denaturing gradient gel electrophoresis (DGGE) and large-scale parallel-pyrosequencing based on the extraction of environmental nucleic acids [7-11].

Numerous procedures exist for the isolation and purification of DNA from soil [1,9,10,12-14]. Studies suggest that the selection of an appropriate extraction and purification procedure depends on the physical and chemical characteristics of the soil matrix, such as organic matter, clay content and $\mathrm{pH}$ value, as well as on different amendments like biochar and poultry manure used in agriculture for improvement of soil fertility [1519]. For example, environmental samples such as soil and sediments often contain high levels of organic matter, especially humic acids and phenolic compounds, as well as heavy metals which can inhibit the activity of the Taq DNA polymerase in PCR [20-22] and reduce the specificity of DNA hybridization analysis [10,23,24].

Indirect and direct approaches have been developed for extracting nucleic acids from soil samples. Indirect extraction of DNA from soil samples is based on the following steps: dispersion of soil particles, separation of 
the cells from soil particles by centrifugation according to sedimentation velocities, buoyant density or both, lysis of extracted cells and finally DNA purification $[1,25,26]$. The most commonly used methods for direct extraction of DNA are based on physical-chemical membrane disruption techniques (bead-beating and freeze-thaw) that may allow greater yields of microbial DNA recovery $[9,12,14,15,20,27,28]$. In spite of many advantages of direct methods, they generally show lower DNA purity with a high degree of DNA shearing that can negatively affect PCR efficiency or specificity $[1,20,27]$. Due to the fact that some of the steps of DNA extraction using these direct methods might make DNA isolation expensive or impractical for processing the large number of samples usually required in ecological studies, commercial kits have been increasingly utilized for DNA extraction and purification from soil and sediments [9,10,14,29-34].

The main goal of this study was to choose a method that would be inexpensive, able to process several samples quickly, and capable of obtaining high quality DNA for PCR studies. Four commercial DNA extraction kits and two physical-chemical methods (bead-beating and freeze-thaw) were compared for the extraction of DNA from a ferro-humic podzol soil amended or not with poultry manure and biochar. No earlier work suggested a mathematical decision aid tool to choose the optimum method for DNA extraction from soil under several conflicting criteria. The present work introduces a systematic/mathematical approach for comparing the performance of different DNA extraction methods under a set of simultaneous "multiple criteria": yield of extraction, purity of extracted DNA $\left(\mathrm{A}_{260 / 280}\right.$ and $\mathrm{A}_{260 / 230}$ ratios), degradation degree of DNA, easiness of PCR amplification, duration of extraction, and cost per extraction. The proposed approach is formally called "multiple criteria decision-making" or MCDM [35].

In problems dealing with MCDM, which is a branch of Operations Research (or OR) models, the main goal is to consider a set of decision criteria and choose the best performing option from a list of available alternatives (i.e., options to choose from), which generally show no obvious dominance one over another with respect to the criteria (this is formally referred to as Pareto optimality or Pareto efficiency condition). More precisely, it is assumed that all given alternatives (e.g., here different DNA extraction techniques) are feasible and there is always a trade-off in choosing one over another. In other words, option A may be better than B under some criteria, but worse under some other criteria. In such complex decision-making scenarios, MCDM can aid the analyst (the decision maker) to make a final decision considering his/her experience, expectations, constraints, etc., into a systematic mathematical model $[35,36]$. It is worth adding that next to selection problems, there are also
MCDM models that are applicable to the sorting and classification problems [37]. The application of MCDM in decision-making processes in molecular biological systems, and more especially in comparing DNA extraction kits, is rather new. Most recently, a basic MCDM model, called "Weighted Sum Method" (WSM) was used for comparing a set of sample preservation and DNA extraction methods from swine feces [38]. Some other example applications of MCDM in a diverse range of practical problems include the use of decision analysis in integrated manufacturing [39], in the evaluation of technology investment decisions [40], in sustainable energy planning [41], and in prioritizing urban cultural heritage values [42].

Despite the fact that WSM is known to be the earliest, the simplest and probably the most widely used MCDM method, it has some shortcomings in particular decision-making cases. Namely, it allows a direct trade-off (compensation) among the criteria values in evaluating the performance of each alternative. As a result, it may choose an alternative that is excellent under some criteria but at the same time poor or close to unacceptablely under some other criteria, which in turn can induce a risk in practice, especially under uncertain data or ambiguous conditions. For instance, a biologist may choose a DNA extraction kit using WSM that gives a very high yield but at the same time the purity of extracted DNA may be at a marginal level, which in turn can pose a primary risk/ concern for that particular decision maker in terms of the quality of DNA. In turn, more advanced MCDM methods have been developed over years, among which is the TOPSIS (the Technique for Order Preference by Similarity to Ideal Solution) method developed by Hwang and Yoon [43]. It carries several advantages such as "simplicity, rationality, comprehensibility, good computational efficiency and ability to measure the relative performance for each alternative in a simple mathematical form" [44]. Most importantly, compared to other simple MCDM methods such as WSM, TOPSIS respects the fact that the decision maker sometimes likes to make as much profit as possible, but also to avoid as much risk as possible. The latter desire is satisfied with TOPSIS by introducing the concept of the ideal and negative-ideal (nadir) solutions. A selected alternative by this method should have the shortest distance from the ideal solution and the farthest distance from the negative-ideal solution in a geometrical sense [43]. The mathematical framework and application of this method in the context of the optimum DNA extraction selection method for agricultural soils are presented in a later section of the present article, which is the main motivation of the work. It should be added that the method is general enough to be applied to other decision-making processes in biological systems. 


\section{MATERIALS AND METHODS}

\subsection{Sample Collection and Preparation}

Soil samples were collected in September 2011 at the Emile A. Lods Agronomy Research Centre of the MacDonald Campus Farm at McGill University, Quebec, Canada, in the range of $5-10 \mathrm{~cm}$ depth of A1 horizon (plowed soil). Collected samples were St-Amable sandy (Ferro-Humic Podzol) soil with the physical-chemical characteristics described in Table 1. Soil was air dried at room temperature to $10 \%-20 \%$ water-holding capacity.

After sieving (stainless soil sieve with $2-\mathrm{mm}$ mesh size), soil samples were stored at $4^{\circ} \mathrm{C}$ in the dark until analysis. Poultry manure was collected from the Poultry Complex of the Macdonald Campus Farm and subsequently air dried at room temperature, homogenized and stored at $4^{\circ} \mathrm{C}$ until analysis. Biochar used in this study was obtained from wood lumbers and wastes by slow pyrolysis at $450^{\circ} \mathrm{C}$ (BlueLeaf Inc., Drummondville, QC, Canada). Mixtures were formulated with soil:manure [SM, 99:1(w/w)] and soil:manure:biochar [SMB, 98:1:1 $(\mathrm{w} / \mathrm{w})]$ and stored at $4^{\circ} \mathrm{C}$ in the dark until analysis.

\subsection{DNA Extraction}

Total bacterial DNA was extracted from soil, soil:manure [SM, 99:1(w/w)] and soil:manure:biochar [SMB, 98:1:1 $(\mathrm{w} / \mathrm{w})$ ] mixtures using six different extraction methods (Table 2). The latter included two previously described home-made methods [38], as summarized below (a bead-beating technique and a freeze-thaw technique), as well as four commercial kits, as described by the manufacturers: PowerSoil ${ }^{\circledR}$ DNA Isolation Kit (MoBio Laboratories, Inc., Carlsbad, CA, USA); UltraClean ${ }^{\mathrm{TM}}$ Soil

Table 1. Physical and chemical characteristics of soil.

\begin{tabular}{|c|c|c|c|c|c|c|}
\hline Soil type & Sand (\%) Silt (\%) & $\mathrm{pH}$ & Bulk density $\left(\mathrm{Mg} \cdot \mathrm{m}^{-3}\right)$ & Organic matter $(\%)$ & Cation exchange capacity $\left(\mathrm{cmol} \cdot \mathrm{kg}^{-1}\right)$ & Hydraulic conductivity $\left(\mathrm{cm} \cdot \mathrm{d}^{-1}\right)$ \\
\hline Sandy & 92.2 & 5.5 & 1.350 & 2.97 & 4.9 & $1.67 \pm 0.45$ \\
\hline
\end{tabular}

Table 2. Comparative analysis of DNA extraction techniques used in this study.

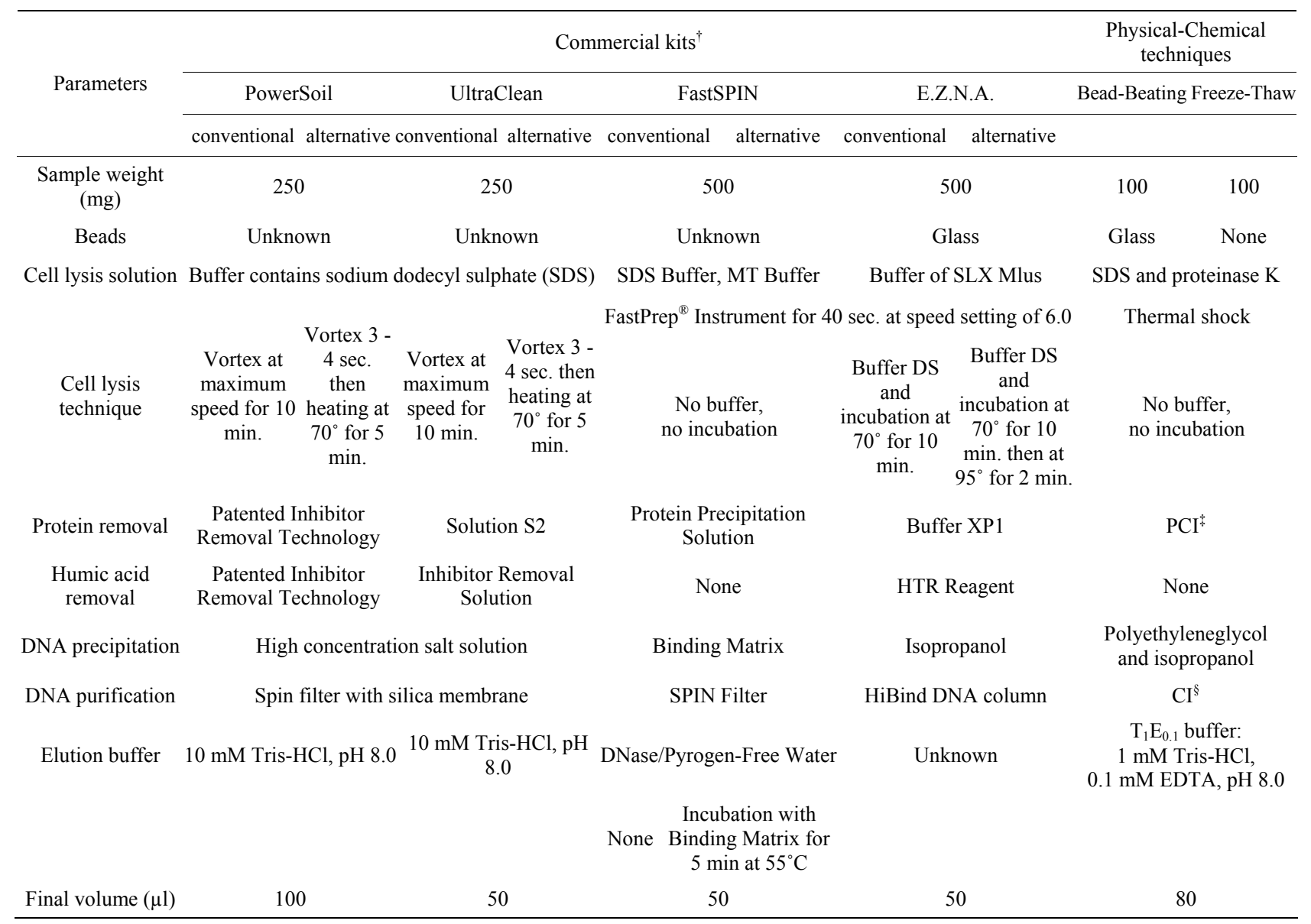

${ }^{\dagger}$ PowerSoil: PowerSoil ${ }^{\circledR}$ DNA Isolation Kit; UltraClean: UltraClean ${ }^{\mathrm{TM}}$ Soil DNA Isolation Kit; FastSPIN: FastDNA ${ }^{\circledR}$ SPIN Kit for Soil; E.Z.N.A.: E.Z.N.A. ${ }^{\circledR}$ Soil DNA Isolation Kit. PCI : phenol:chloroform:isoamyl alcohol, 25:24:1 (v/v); $\mathrm{CI}^{\S}$ : chloroform:isoamyl alcohol, 24:1 (v/v). 
DNA Isolation Kit (MoBio Laboratories, Inc., Carlsbad, CA, USA); FastDNA ${ }^{\circledR}$ SPIN Kit for Soil (MP Biomedicals, LLC, Solon, OH, USA); E.Z.N.A. ${ }^{\circledR}$ Soil DNA Isolation Kit (Omega Bio-Tek, Inc., Carlsbad, CA, USA). Next to the conventional procedure for each of the four DNA extraction commercial kits, to reduce DNA shearing and/or increase DNA yields, alternative lysis methods were assessed as described by the manufacturers (Table 2), hence resulting in a total of 10 methods including the home-made methods.

\section{Bead-Beating and Freeze-Thaw Methods}

Soil, soil:manure [SM, 99:1(w/w)] and soil:manure:biochar [SMB, 98:1:1(w/w)] mixtures $(0.1 \mathrm{~g})$ were resuspended in $1 \mathrm{ml}$ of extraction buffer $(500 \mathrm{mM}$ Tris- $\mathrm{HCl}$ pH 8.0, $100 \mathrm{mM}$ sodium EDTA pH 8.0, 1.5 M NaCl) and homogenized by vortexing. For disrupting cells by beadbeating, $0.1 \mathrm{~g}$ of $0.1 \mathrm{~mm}$-diameter glass beads (BioSpec Products, Bartlesville, OK, USA) were added and cells were disrupted by shaking the tubes for $40 \mathrm{sec}$ (speed $=$ 6.0) in a Fast-Prep (Bio101 Fast-Prep model FP120, Thermo Savant, Qiagen, Inc., Carlsbad, CA, USA), leaving on ice for $5 \mathrm{~min}$ (to counteract heating of the tubes in the Fast-Prep), and shaking a second time for $40 \mathrm{sec}$ (speed $=6.0$ ). For disrupting cells by freeze-thaw, three cycles of freezing in liquid nitrogen $\left(-196^{\circ} \mathrm{C}\right)$ for $5 \mathrm{~min}$ and thawing at $65^{\circ} \mathrm{C}$ in a water bath for 10 min were used.

Subsequent procedures for DNA purification after both bead-beating and freeze-thaw were the same. After physical disruption of the cells either by bead-beating or freeze-thaw, $20 \mu \mathrm{l}$ of proteinase $\mathrm{K}$ were added and tubes were incubated at $37^{\circ} \mathrm{C}$ with shaking at $180 \mathrm{rpm}$ for 30 min to digest contaminating proteins. One hundred microliters of $20 \%$ (w/v) SDS (sodium dodecyl sulfate) were added, tubes were mixed by inverting several times, incubated at $65^{\circ} \mathrm{C}$ for $1 \mathrm{~h}$ and centrifuged at $12,000 \times \mathrm{g}$ for $5 \mathrm{~min}$. The supernatants were transferred to new tubes containing 0.5 volume of polyethylene glycol (PEG) solution $[30 \%(\mathrm{w} / \mathrm{v})$ PEG, $1.5 \mathrm{M} \mathrm{NaCl}]$ and incubated at room temperature for $2 \mathrm{~h}$. Tubes were centrifuged at $16,100 \times \mathrm{g}$ for $20 \mathrm{~min}$. The pellets were dissolved in $90 \mu \mathrm{l}$ of $\mathrm{T}_{1} \mathrm{E}_{0.1}$ buffer $(1 \mathrm{mM}$ Tris-HCl, $0.1 \mathrm{mM}$ EDTA, pH 8.0). Thirty microliters of ammonium acetate $10 \mathrm{M}$ were added, tubes were mixed by inverting several times and left on ice for 5 min to counteract heating. Tubes were centrifuged at $16,100 \times \mathrm{g}$ for $30 \mathrm{~min}$ at $4^{\circ} \mathrm{C}$ to precipitate proteins and polysaccharides. The DNA was purified from the aqueous phase by phenolchloroform-isoamyl alcohol extraction [25:24:1 (v/v)] followed by chloroform-isoamyl alcohol extraction [24:1 (v/v)]. The DNA was precipitated by adding 0.6 volume of isopropanol and incubating at $-20^{\circ} \mathrm{C}$ for $1 \mathrm{~h}$. DNA was collected by centrifuging at $16,100 \times \mathrm{g}$ for $10 \mathrm{~min}$ at $4^{\circ} \mathrm{C}$.
The pellets were washed twice with $70 \%$ ethanol. After air drying for about $30 \mathrm{~min}$, the pellets were resuspended in $80 \mu \mathrm{l}$ of $\mathrm{T}_{1} \mathrm{E}_{0.1}$ buffer $(1 \mathrm{mM}$ Tris- $\mathrm{HCl}, 0.1$ mM EDTA, $\mathrm{pH}$ 8.0). The resulting extracts were treated with $10 \mu \mathrm{g}$ of RNAse (Invitrogen, Burlington, ON, Canada) for $10 \mathrm{~min}$ at $37^{\circ} \mathrm{C}$, and stored at $-20^{\circ} \mathrm{C}$.

\subsection{Polymerase Chain Reaction Amplification}

PCR amplifications were carried out in a Veriti ${ }^{\mathrm{TM}}$ Thermal Cycler (Applied Biosystems, Foster City, CA, USA) using 10 ng of DNA extracted from each sample by each DNA extraction technique as template. The V3 region of the bacteria $16 \mathrm{~S}$ rDNA was targeted using the Bacteria universal primers $341 \mathrm{~F}$ (forward primer:

CCTACGGGAGGCAGCAG) and 534R (reverse primer: ATTACCGCGGCTGCTGG), which yield amplicons of about 193 bp [45]. The PCR reaction mixture contained $0.75 \mu \mathrm{M}$ of each primer, $200 \mu \mathrm{M}$ of each dNTP (Amersham Biosciences Corp., Piscataway, NJ, USA), 1.25 U Taq DNA polymerase (Invitrogen, Burlington, ON, Canada), and the PCR buffer supplied with the enzyme (10 mM Tris- $\mathrm{HCl} \mathrm{pH}$ 9.0, $50 \mathrm{mM} \mathrm{KCl}, 1.5 \mathrm{mM} \mathrm{MgCl}_{2}$ ) [46]. For each DNA extract, the following series of PCR tubes were analyzed for the presence of the V3 region of the bacteria $16 \mathrm{~S}$ rDNA: 1) triplicate PCR tubes with 10 $\eta g$ of extracted DNA; 2) a positive control tube with 10 $\eta g$ of DNA extracted from a pure culture of Escherichia coli ATCC 25922; 3) an inhibition control tube with 5 ๆg of DNA extracted from a pure culture of E. coli ATCC 25922 and $5 \eta \mathrm{g}$ of DNA extracted from each sample, in order to assess the presence of PCR inhibitors in the extracts; 4) a negative control tube consisting of the reaction mixture without DNA, in order to assess the presence of external or cross-contamination of the PCR reaction mixtures by DNA.

The PCR conditions were $5 \mathrm{~min}$ at $99^{\circ} \mathrm{C}$ (initial denaturation), then 2 cycles of $5 \mathrm{~min}$ at $94^{\circ} \mathrm{C}$ (denaturation), 5 min at $55^{\circ} \mathrm{C}$ (annealing) and $2 \mathrm{~min}$ at $72^{\circ} \mathrm{C}$ (extension), then 28 cycles of $1 \mathrm{~min}$ at $94^{\circ} \mathrm{C}$ (denaturation), $1 \mathrm{~min}$ at $55^{\circ} \mathrm{C}$ (annealing), $2 \mathrm{~min}$ at $72^{\circ} \mathrm{C}$ (extension), and finally an extension period of $10 \mathrm{~min}$ at $72^{\circ} \mathrm{C}$. The size (about $193 \mathrm{bp}$ ), specificity (unique band), and abundance of PCR products were determined by comparison with DNA standards (GeneRuler 100 bp DNA Ladder, MBI Fermentas, Burlington, ON, Canada) after agarose gel electrophoresis [46].

\subsection{Identifying a Set of Criteria for Comparing DNA Extraction Methods}

All DNA extractions were performed in 5 replicates. For each of the following criteria, errors are indicated in Table 3 as the standard deviation of 3 replicate measurements on 5 replicate extractions $(n=15)$. 
Table 3. Performance of each DNA extraction method under seven decision criteria for soil, SM [soil:manure, 99:1(w/w)] and SMB [soil:manure:biochar, 98:1:1(w/w)].

\begin{tabular}{|c|c|c|c|c|c|c|c|c|}
\hline \multirow{3}{*}{ Methods $^{\dagger}$} & \multirow{3}{*}{ Sample } & \multicolumn{7}{|c|}{ Performance/Decision Criteria } \\
\hline & & $C_{1}$ & $C_{2}$ & $C_{3}$ & $C_{4}$ & $C_{5}$ & $C_{6}$ & $C_{7}$ \\
\hline & & $\begin{array}{l}\text { Yield ( } \mu \text { g DNA/g } \\
\text { sample) }\end{array}$ & $\mathrm{A}_{260 / 280}$ ratio & $\mathrm{A}_{260 / 230}$ ratio & $\begin{array}{c}\text { Degree of DNA } \\
\text { degradation }\end{array}$ & $\begin{array}{c}\text { Easiness of } \\
\text { amplification }^{\#}\end{array}$ & $\begin{array}{c}\text { Duration of } \\
\text { extraction (hrs.) }\end{array}$ & $\begin{array}{l}\text { Cost per extraction } \\
\text { (CAD })^{\dagger \dagger}\end{array}$ \\
\hline \multirow{3}{*}{$\begin{array}{l}\text { UltraClean } \\
\text { Conventional }\end{array}$} & Soil & $8.21 \pm 1.32^{\ddagger}$ & $1.75 \pm 0.02$ & $1.30 \pm 0.05$ & 2 & 2 & 0.83 & 4.64 \\
\hline & SM & $14.21 \pm 1.24$ & $1.71 \pm 0.06$ & $1.43 \pm 0.20$ & 2 & 2 & 0.83 & 4.64 \\
\hline & SMB & $13.03 \pm 1.23$ & $1.77 \pm 0.04$ & $1.21 \pm 0.30$ & 2 & 2 & 0.83 & 4.64 \\
\hline \multirow{3}{*}{$\begin{array}{l}\text { UltraClean } \\
\text { Alternative }\end{array}$} & Soil & $5.59 \pm 0.58$ & $1.63 \pm 0.23$ & $1.22 \pm 0.06$ & 1 & 2 & 0.92 & 4.64 \\
\hline & SM & $10.77 \pm 1.39$ & $1.50 \pm 0.04$ & $0.81 \pm 0.04$ & 1 & 2 & 0.92 & 4.64 \\
\hline & SMB & $9.40 \pm 1.36$ & $1.53 \pm 0.06$ & $0.88 \pm 0.03$ & 1 & 2 & 0.92 & 4.64 \\
\hline \multirow{3}{*}{$\begin{array}{c}\text { PowerSoil } \\
\text { Conventional }\end{array}$} & Soil & $6.76 \pm 0.84$ & $1.67 \pm 0.08$ & $1.28 \pm 0.18$ & 1 & 2 & 1.00 & 5.54 \\
\hline & SM & $10.52 \pm 1.69$ & $1.96 \pm 0.05$ & $1.67 \pm 0.13$ & 1 & 2 & 1.00 & 5.54 \\
\hline & SMB & $8.75 \pm 1.43$ & $1.90 \pm 0.07$ & $1.57 \pm 0.15$ & 1 & 2 & 1.00 & 5.54 \\
\hline \multirow{3}{*}{$\begin{array}{l}\text { PowerSoil } \\
\text { Alternative }\end{array}$} & Soil & $3.78 \pm 0.32$ & $1.74 \pm 0.34$ & $2.07 \pm 0.10$ & 1 & 2 & 1.08 & 5.54 \\
\hline & SM & $10.48 \pm 3.58$ & $1.55 \pm 0.06$ & $0.86 \pm 0.11$ & 1 & 2 & 1.08 & 5.54 \\
\hline & SMB & $11.97 \pm 2.17$ & $1.55 \pm 0.05$ & $0.96 \pm 0.11$ & 1 & 2 & 1.08 & 5.54 \\
\hline \multirow{3}{*}{$\begin{array}{l}\text { FastSpin } \\
\text { Conventional }\end{array}$} & Soil & $17.70 \pm 1.72$ & $1.73 \pm 0.02$ & $0.25 \pm 0.02$ & 3 & 1 & 1.16 & 6.58 \\
\hline & SM & $20.00 \pm 1.64$ & $1.77 \pm 0.03$ & $0.39 \pm 0.04$ & 3 & 1 & 1.16 & 6.58 \\
\hline & SMB & $23.87 \pm 2.60$ & $1.84 \pm 0.02$ & $0.60 \pm 0.07$ & 3 & 1 & 1.16 & 6.58 \\
\hline \multirow{3}{*}{$\begin{array}{l}\text { FastSpin } \\
\text { Alternative }\end{array}$} & Soil & $23.29 \pm 1.54$ & $1.70 \pm 0.02$ & $0.34 \pm 0.12$ & 3 & 1 & 1.25 & 6.58 \\
\hline & SM & $20.36 \pm 0.88$ & $1.77 \pm 0.04$ & $0.50 \pm 0.09$ & 3 & 1 & 1.25 & 6.58 \\
\hline & SMB & $21.45 \pm 1.95$ & $1.79 \pm 0.01$ & $0.47 \pm 0.01$ & 3 & 1 & 1.25 & 6.58 \\
\hline \multirow{3}{*}{$\begin{array}{c}\text { E.Z.N.A. } \\
\text { Conventional }\end{array}$} & Soil & $4.33 \pm 0.18$ & $1.67 \pm 0.08$ & $0.43 \pm 0.42$ & 3 & 1 & 3.17 & 4.38 \\
\hline & SM & $7.26 \pm 0.1 .30$ & $1.85 \pm 0.06$ & $1.57 \pm 0.28$ & 3 & 1 & 3.17 & 4.38 \\
\hline & SMB & $7.69 \pm 0.1 .32$ & $1.87 \pm 0.06$ & $1.70 \pm 0.16$ & 3 & 1 & 3.17 & 4.38 \\
\hline \multirow{3}{*}{$\begin{array}{l}\text { E.Z.N.A. } \\
\text { Alternative }\end{array}$} & Soil & $25.98 \pm 4.86$ & $1.56 \pm 0.02$ & $0.30 \pm 0.20$ & 3 & 1 & 3.25 & 4.38 \\
\hline & SM & $25.90 \pm 2.92$ & $1.57 \pm 0.04$ & $0.55 \pm 0.20$ & 3 & 1 & 3.25 & 4.38 \\
\hline & SMB & $15.73 \pm 3.53$ & $1.65 \pm 0.01$ & $0.47 \pm 0.33$ & 3 & 1 & 3.25 & 4.38 \\
\hline \multirow{3}{*}{ Bead-Beating } & Soil & $5.24 \pm 1.03$ & $0.77 \pm 0.05$ & $0.12 \pm 0.01$ & $\mathrm{ND}^{\pi}$ & 3 & 7.5 & 1 \\
\hline & SM & $6.53 \pm 0.36$ & $0.87 \pm 0.06$ & $0.11 \pm 0.01$ & ND & 3 & 7.5 & 1 \\
\hline & SMB & $4.87 \pm 0.44$ & $0.78 \pm 0.09$ & $0.09 \pm 0.01$ & ND & 3 & 7.5 & 1 \\
\hline \multirow{3}{*}{ Freeze-Thaw } & Soil & $5.49 \pm 1.10$ & $1.13 \pm 0.18$ & $0.19 \pm 0.07$ & ND & 3 & 8.5 & 1 \\
\hline & SM & $6.21 \pm 0.64$ & $0.85 \pm 0.07$ & $0.11 \pm 0.01$ & ND & 3 & 8.5 & 1 \\
\hline & SMB & $8.90 \pm 2.73$ & $0.86 \pm 0.06$ & $0.13 \pm 0.02$ & ND & 3 & 8.5 & 1 \\
\hline
\end{tabular}

${ }^{\dagger}$ UltraClean: UltraClean ${ }^{\mathrm{TM}}$ Soil DNA Isolation Kit; PowerSoil: PowerSoil ${ }^{\circledR}$ DNA Isolation Kit; FastSPIN: FastDNA ${ }^{\circledR}$ SPIN Kit for Soil; E.Z.N.A.: E.Z.N.A. ${ }^{\circledR}$ Soil DNA Isolation Kit. PCI; ${ }^{\star}$ : Each test was repeated five times and the \pm values refer to their standard deviations. ${ }^{\S}$ Degree of DNA degradation (Lemarchand et al., 2005): 1 = low (mean fragment size between 23 and $2 \mathrm{~kb}$ ); 2 = medium (mean fragment size between 23 and $0.5 \mathrm{~kb}$ ); $3=$ high (mean fragment size between 23 and $<0.5 \mathrm{~kb}$ ). ${ }^{\#} 1=$ low (mean fragment size between 23 and $2 \mathrm{~kb}$ ); $2=$ medium (mean fragment size between 23 and $0.5 \mathrm{~kb}$ ); $3=$ high (mean fragment size between 23 and $<0.5 \mathrm{~kb}$ ); ${ }^{\dagger \dagger}$ Canadian dollars; ${ }^{\top}$ Not determined since extracted DNA was not visible on the agarose gel stained with ethidium bromide. 
DNA concentration (ng DNA $\left.\mu \mathrm{I}^{-1}\right), \mathrm{A}_{260 / 280}$ ratio (absorbance at $260 \eta \mathrm{m} /$ absorbance at $280 \eta \mathrm{m}$ ) and $\mathrm{A}_{260 / 230}$ ratio (absorbance at $260 \eta \mathrm{m} /$ absorbance at $230 \eta \mathrm{m}$ ) of each extract were determined using a NanoDrop 2000 Spectrophotometer (Thermo Fisher Scientific, Marietta, OH, USA). The yield for each DNA extraction method was calculated as follows: Yield of extraction ( $\mu \mathrm{g}$ of $\mathrm{DNA} / \mathrm{g}$ of sample $)=$ concentration of DNA in the extract $(\eta \mathrm{g} / \mu \mathrm{l}) \times(1 \mu \mathrm{g} / 1000 \eta \mathrm{g}) \times$ final volume of extract $(\mu \mathrm{l}) /$ dry weight of sample $(\mathrm{g})$.

The $A_{260 / 280}$ ratio and the $A_{260 / 230}$ ratio were used to evaluate the purity of DNA extracts. An $\mathrm{A}_{260 / 280}$ ratio higher than 1.8 indicates the absence of proteins in DNA extracts. When the $\mathrm{A}_{260 / 280}$ ratio is lower than 1.8, proteins or other contaminants (co-extracted with DNA) that absorb strongly at or near $280 \eta \mathrm{m}$ may be present. An $\mathrm{A}_{260 / 280}$ ratio over 2.0 indicates RNA contamination of the sample.

An $\mathrm{A}_{260 / 230}$ ratio between 2.0 and 2.2 is indicative of the high purity of extracted DNA. When the $\mathrm{A}_{260 / 230}$ ratio is lower than 2, humic acids, carbohydrates, phenol, guanidine $\mathrm{HCl}$ or other contaminants that absorb at or near $230 \eta \mathrm{m}$, may be presented [47].

The DNA in each extract was checked for integrity (degradation degree) by agarose gel electrophoresis by comparing with Lambda DNA HindIII Digest standards (New England BioLabs, Ipswich, MA, USA) using AlphaEaseFC software version 3.1.2 (AlphaInnotech Corporation, San Leandro, CA, USA). The degradation degree of the DNA in each extract was evaluated using the scale proposed by Lemarchand et al. (2005): 1 = low (mean fragment size between 23 and $2 \mathrm{~kb}$ ); 2 = medium (mean fragment size between 23 and $0.5 \mathrm{~kb}$ ); $3=$ high (mean fragment size between 23 and $<0.5 \mathrm{~kb}$ ).

In addition to the above, in this study we used a new criterion "Easiness of amplification" for comparing the ten DNA extraction methods (Table 2). The number of PCR bands as well as the presence or absence of Taq DNA polymerase inhibitors dictated the "Easiness of amplification", which was expressed by a quantitative scheme as follows: [ $1=$ easy to perform (one band detected, absence of inhibitors), 2 = moderately difficult to perform ( 1 band detected and presence of inhibitors, or 2 bands detected and absence of inhibitors), 3 = very difficult to perform (2 bands detected and presence of inhibitors, or no band detected)].

Two other criteria, namely duration of extraction and cost per extraction, were included for a total of seven decision criteria to compare the ten different DNA extraction methods and choose the best one via a systematic mathematical method as follows.

\subsection{Multiple Criteria Decision-Making (MCDM): The Entropy and TOPSIS Techniques}

A decision-making process often involves making pref- erence decisions over multitude alternatives (given options) that are characterized by multiple, usually conflicting criteria (Ahn, 2011). A typical decision matrix, $X$, used in MCDM is shown in Figure 1, where $C_{j}$ represent the decision criteria $(j=1, \cdots, n) ; \mathrm{A}_{i}$ represent the alternatives $(i=1, \cdots, m)$, and $x_{i j}$ represent the value of the $i$-th alternative under the $j$-th criterion. $W_{j}(j=1, \cdots, n)$ are the criteria weights, indicating the relative importance among them.

Among different criteria weight assignment techniques used in the MCDM field, the "Entropy" method is among the very few techniques that are independent of the decision maker's subjective priorities/judgments. In the entropy method, the criteria weights are calculated based on the actual measured data in the decision matrix; i.e., by means of an objective/statistical process.

Following Section 2.4 in the present study, the ten different DNA extraction methods (alternatives) are to be compared under seven performance criteria $\left(C_{j}, j=1\right.$, $2, \cdots, 7)$ including: $\left(C_{1}\right)$ yield of extraction (the higher the better); $\left(C_{2}\right) \mathrm{A}_{260 / 280}$ ratio (the higher the better); $\left(C_{3}\right)$ $\mathrm{A}_{260 / 230}$ ratio (the higher the better); $\left(C_{4}\right)$ degree of DNA degradation (the lower the better); $\left(C_{5}\right)$ easiness of amplification ranking index (the lower the better); $\left(C_{6}\right)$ duration of extraction (the lower the better); and $\left(C_{7}\right)$ cost per extraction (the lower the better). Decision weights using the entropy technique were calculated for all criteria via the following steps [48].

Step 1. Transferring the decision matrix to the normalized mode.

In order to adjust the entropy measure for the $j$-th criterion, the related values in the decision matrix are first normalized as $P_{i j}$;

$$
P_{i j}=\frac{x_{i j}}{\sum_{i}^{m} x_{i j}}
$$

Step 2. Calculating the entropy of dataset for each criterion.

In this step, the entropy of the $j$-th criterion, $E_{j}$, is calculated as follows:

$$
\begin{aligned}
& E_{j}=-a \sum_{i=1}^{m} p_{i j} \operatorname{In} p_{i j} \\
& (i=1,2, \cdots, m),(j=1,2, \cdots, n) \\
& \begin{array}{ccccc}
\text { criteria } & C_{1} & C_{2} & \ldots & C_{n}
\end{array} \\
& \left(\begin{array}{lllll}
\text { weights } & w_{1} & w_{2} & \cdots & w_{n}
\end{array}\right)
\end{aligned}
$$

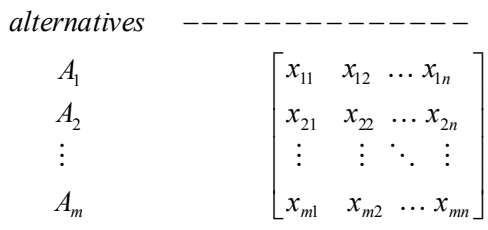

Figure 1. A typical decision matrix in MCDM. 
where, $\alpha=1 / \ln (m)$; " $m$ " is the total number of alternatives (in this study, the DNA extraction methods over different samples);

Next, the operation of subtraction is used to measure the degree of diversity relative to the corresponding anchor value (unity), $D_{j}$, using the following formula:

$$
D_{j}=1-E_{j}
$$

\section{Step 3. Defining criteria weights.}

The entropy weight of each criterion is calculated using:

$$
W_{j}=D_{j} / \sum_{i=1}^{m} D_{j}
$$

These weights are then incorporated into the so-called TOPSIS MCDM technique to calculate an overall score for each DNA extraction method. The TOPSIS technique was chosen because of its high speed, accuracy, and compatibility [49]. The algorithm of this technique is summarized as follows:

1) Transfer the decision matrix to the normalized mode;

$$
r_{i j}=\frac{x_{i j}}{\sqrt{\sum_{i=1}^{m} x_{i j}^{2}}}(i=1,2, \cdots, m),(j=1,2, \cdots, n)
$$

2) Weigh the normalized decision matrix;

$$
v_{i j}=W_{j} \times r_{i j}(i=1,2, \cdots, m),(j=1,2, \cdots, n)
$$

3) Define the "ideal positive" $V_{j}^{+}$and "ideal negative (nadir)" $V_{j}^{-}$solutions;

$$
\left\{\begin{array}{l}
\left\{V_{1}^{+}, V_{2}^{+}, \cdots, V_{n}^{+}\right\}=\left\{\left(\max _{i} V_{i j} \mid j \in J\right),\right. \\
\left.\left(\min _{i} V_{i j} \mid j \in J^{\prime}\right) \mid i=1,2, \cdots, m\right\} \\
\left\{V_{1}^{-}, V_{2}^{-}, \cdots, V_{n}^{-}\right\}=\left\{\left(\max _{i} V_{i j} \mid j \in J\right),\right. \\
\left.\left(\max _{i} V_{i j} \mid j \in J^{\prime}\right) \mid i=1,2, \cdots, m\right\}
\end{array}\right.
$$

4) Measure the distances, $d_{i}^{+}$and $d_{i}^{-}, i=1,2, \cdots, n$, from the ideal and negative ideal solutions;

$$
\left\{\begin{array}{l}
d_{i}^{+}=\left[\sum_{i=1}^{n}\left(V_{i j}-V_{j}^{+}\right)^{2}\right]^{1 / 2}, i=1,2, \cdots, m \\
d_{i}^{-}=\left[\sum_{i=1}^{n}\left(V_{i j}-V_{j}^{-}\right)^{2}\right]^{1 / 2}, i=1,2, \cdots, m
\end{array}\right.
$$

5) Determine the relative closeness of alternatives to the ideal solution;

$$
C_{i}^{+}=\frac{d_{i}^{-}}{d_{i}^{+}+d_{i}^{-}}, i=1,2, \cdots, m
$$

where $0 \leq C_{i}^{+} \leq 1$. Alternatives with higher magnitudes of closeness $C_{i}^{+}$are more preferred.

\section{RESULTS}

\subsection{Revealing Conflicts among the Selection Criteria: A One-Criterion-at-a-Time Analysis}

The performance of the ten DNA extraction methods under the seven decision criteria for soil, SM [soil:manure, 99:1(w/w)] and SMB [soil:manure:biochar, 98:1:1 $(\mathrm{w} / \mathrm{w})$ ] are displayed in Table 3 (which in fact can be considered as the given decision matrix in the MCDM terminology). Altogether, 30 different DNA extracts were obtained (10 extraction methods for each of the three sample types). Subsequently, using the values presented in Table 3, the 10 extraction methods were evaluated by seven decision criteria for each of the three sample types and were ranked in Table 4. The ranking results in Table 4 show that the E.Z.N.A alternative extraction method provided the highest yield of extraction for soil and SM samples, whereas for SMB samples, the FastSPIN conventional method had the best performance in terms of yield of extraction compared to the other commercial kits and home-made physical-chemical techniques.

Under the purity (ratio $\mathrm{A}_{260 / 280}$ and $\mathrm{A}_{260 / 230}$ ) criteria, the PowerSoil conventional and E.Z.N.A. conventional methods ranked $1^{\text {st }}$ and $2^{\text {nd }}$, respectively, for SM and SMB samples (Table 4). In contrast, under the $\mathrm{A}_{260 / 280}$ criterion for soil samples, the UltraClean conventional method gained the first rank, followed by the PowerSoil alternative method. However, under the $\mathrm{A}_{260 / 230}$ criterion for soil samples, the latter method gained the first rank and the UltraClean conventional method received the second rank.

The degree of degradation of extracted DNA also varied depending on the extraction technique applied (Table 3). It was the highest when the conventional and alternative lysis methods of the FastSPIN and E.Z.N.A. kits were used (Table 4), and was the lowest using the PowerSoil conventional and alternative methods as well as the UltraClean alternative method. Among all commercial kits, it is also worth noticing from Table 3 that the UltraClean kit was the only one for which the alternative method reduced the degree of DNA degradation.

Under the "Easiness of amplification" criterion, consistent specific PCR amplification (unique band) of $~ 193$ bp amplicons corresponding to the V3 region of the Bacteria 16S rDNA was successfully obtained for DNA extracted from soil, SM and SMB mixtures using both conventional and alternative methods of FastSPIN and E.Z.N.A. (results not shown): hence they resulted in the top rank under this criterion (Table 4). In contrast, two bands were detected after amplification of DNA extracted from soil, SM and SMB mixtures using both conventional and alternative methods of UltraClean and PowerSoil commercial kits (results not shown). In addi- 
Table 4. Ranks of DNA extraction methods for seven decision criteria; each group of three numbers separated with commas indicate: soil, SM [soil:manure, 99:1(w/w)] and SMB [soil:manure:biochar, 98:1:1(w/w)].

\begin{tabular}{cccccccc}
\hline & \multicolumn{7}{c}{ Ranks in decision criteria $^{\ddagger}$} \\
\cline { 2 - 7 } Methods $^{\dagger}$ & \multicolumn{1}{c}{$C_{1}$} & $C_{2}$ & $C_{3}$ & $C_{4}$ & $C_{5}$ & $C_{6}$ & $C_{7}$ \\
\cline { 2 - 7 } & Yield of extraction & $\mathrm{A}_{260 / 280}$ ratio & $\mathrm{A}_{260 / 230}$ ratio & $\begin{array}{c}\text { Degree of DNA } \\
\text { degradation }\end{array}$ & $\begin{array}{c}\text { Easiness of } \\
\text { amplification }\end{array}$ & $\begin{array}{c}\text { Duration of } \\
\text { extraction }\end{array}$ & $\begin{array}{c}\text { Cost per } \\
\text { extraction }\end{array}$ \\
\hline UltraClean Conventional & $4,4,4$ & $1,5,5$ & $2,3,3$ & $2,2,2$ & $2,2,2$ & $1,1,1$ & $3,3,3$ \\
UltraClean Alternative & $6,5,6$ & $7,8,8$ & $4,5,5$ & $1,1,1$ & $2,2,2$ & $2,2,2$ & $3,3,3$ \\
PowerSoil Conventional & $5,6,8$ & $5,1,1$ & $3,1,1$ & $1,1,1$ & $2,2,2$ & $3,3,3$ & $4,4,4$ \\
PowerSoil Alternative & $10,7,5$ & $2,7,7$ & $1,4,4$ & $1,1,1$ & $2,2,2$ & $4,4,4$ & $4,4,4$ \\
FastSpin Conventional & $3,3,1$ & $3,3,3$ & $8,8,6$ & $3,3,3$ & $1,1,1$ & $5,5,5$ & $5,5,5$ \\
FastSpin Alternative & $2,2,2$ & $4,4,4$ & $7,7,8$ & $3,3,3$ & $1,1,1$ & $6,6,6$ & $5,5,5$ \\
E.Z.N.A. Conventional & $9,8,9$ & $6,2,2$ & $6,2,2$ & $3,3,3$ & $1,1,1$ & $7,7,7$ & $2,2,2$ \\
E.Z.N.A. Alternative & $1,1,3$ & $8,6,6$ & $5,6,7$ & $3,3,3$ & $1,1,1$ & $8,8,8$ & $2,2,2$ \\
Bead-Beating & $8,9,10$ & $10,9,10$ & $10,9,10$ & $\mathrm{ND}^{*}$ & $3,3,3$ & $9,9,9$ & $1,1,1$ \\
Freeze-Thaw & $7,10,7$ & $9,10,9$ & $9,10,9$ & $\mathrm{ND}^{*}$ & $3,3,3$ & $10,10,10$ & $1,1,1$ \\
\hline
\end{tabular}

${ }^{\dagger}$ UltraClean: UltraClean ${ }^{\mathrm{TM}}$ Soil DNA Isolation Kit; PowerSoil: PowerSoil ${ }^{\circledR}$ DNA Isolation Kit; FastSPIN: FastDNA ${ }^{\circledR}$ SPIN Kit for Soil; E.Z.N.A.: E.Z.N.A. ${ }^{\circledR}$ Soil DNA Isolation Kit. ${ }^{\ddagger}$ Rank of each DNA extraction method for soil, soil:manure, and soil:manure:biochar, respectively, under each decision criterion. ${ }^{*}$ : Not determined.

tion, no band was detected after amplification of DNA extracted by the Bead-Beating and Freeze-Thaw techniques. These results imply a requirement for optimization of the PCR reaction mixture and/or program, as well as the necessity for assessing the presence of Taq DNA polymerase inhibitor(s).

For DNA extracted by both conventional and alternative methods of the four commercial kits as well as home-made methods (Bead-Beating and Freeze-Thaw techniques), the specific amplification of $\sim 193 \mathrm{bp}$ amplicons was obtained for each extract in the inhibition controls (mixture of DNA extracted from E. coli ATCC 25922 and DNA extracted from each sample), indicating the absence of $T a q$ DNA polymerase inhibitors in the extracts from these DNA extraction techniques. The absence of PCR band is in line with the low yields and purities of DNA extracted with these two techniques (Table 3), making them hold the lowest $\left(3^{\text {rd }}\right)$ rank under the easiness of amplification criterion.

The duration of extraction and the cost per extraction are also very important in selecting an optimum DNA extraction technique in view of processing a large number of environmental samples in ecological studies. Under the duration of extraction criterion, UltraClean conventional method obtained the first rank, followed by the alternative type of UltraClean method (Table 4). The home-made Bead-Beating and Freeze-Thaw techniques performed the poorest under all the criteria except for the cost where they were ranked as the preferred options (least costly). Since the DNA extracted with the BeadBeating and Freeze-Thaw methods was not visible on the agarose gel stained with ethidium bromide because of very low concentrations ( 6.08 and $8.16 \mathrm{ng}$ of DNA/ $\mu$ l of extract, respectively, Table 3), the degree of DNA degradation could not be determined.

The above comparison of the DNA extraction methods under each criterion individually (Table 4) clearly demonstrates the presence of conflicts among criteria in the given decision-making problem. An example of such conflict is for the FastSpin conventional extraction method which resulted in a good performance in terms of yield of DNA extraction from soil, SM, and SMB (ranks of 3, 3, and 1 respectively), but performed poorly under the degree of DNA degradation criterion. In contrast, the DNA extracted by the E.Z.N.A. conventional method offered a good performance under Easiness of amplification (rank 1 for all three sample types), but its yield of extraction was one of the lowest (ranks of 9, 8, and 9 for soil, SM, and SMB, respectively). Because of such conflicts, the MCDM Entropy-TOPSIS approach was deemed necessary and implemented in order to choose overall the best DNA extraction method under simultaneous decision-making criteria for each specific soil mixture.

\subsection{Multiple Criteria Decision-Making (MCDM): The Entropy Method}

Following Section 2.5, as the first step to the MCDM solution, criteria importance weights needed to be calculated for all seven criteria for soil, SM and SMB using the entropy method according to Formulas $1-4$. For example, to calculate the weight of criterion $C_{1}$ for DNA extraction from soil, the normalization was first performed to calculate $p_{i j}$ values using formula 1 (Table 5). Then, $p_{i j} \times \ln \left(p_{i j}\right)$ values were calculated (see the exam- 
Table 5. Normalized decision matrix for DNA extraction methods for soil.

\begin{tabular}{|c|c|c|c|c|c|c|c|}
\hline \multirow{3}{*}{ Methods $^{\dagger}$} & \multicolumn{7}{|c|}{ Normalized Decision Matrix Data $\left(\mathrm{p}_{\mathrm{ij}}\right)$} \\
\hline & $C_{1}$ & $C_{2}$ & $C_{3}$ & $C_{4}$ & $C_{5}$ & $C_{6}$ & $C_{7}$ \\
\hline & $\begin{array}{l}\text { Yield of } \\
\text { extraction }\end{array}$ & $\begin{array}{l}\mathrm{A}_{260 / 280} \\
\text { ratio }\end{array}$ & $\begin{array}{l}\mathrm{A}_{260 / 230} \\
\text { ratio }\end{array}$ & $\begin{array}{c}\text { Degree of DNA } \\
\text { degradation }\end{array}$ & $\begin{array}{c}\text { Easiness of } \\
\text { amplification }\end{array}$ & $\begin{array}{l}\text { Duration of } \\
\text { extraction }\end{array}$ & $\begin{array}{l}\text { Cost per } \\
\text { extraction }\end{array}$ \\
\hline UltraClean Conventional & $0.09 \$$ & 0.13 & 0.18 & 0.12 & 0.10 & 0.07 & 0.11 \\
\hline UltraClean Alternative & 0.06 & 0.12 & 0.16 & 0.06 & 0.10 & 0.07 & 0.11 \\
\hline PowerSoil Conventional & 0.07 & 0.12 & 0.17 & 0.06 & 0.10 & 0.08 & 0.13 \\
\hline PowerSoil Alternative & 0.04 & 0.13 & 0.28 & 0.06 & 0.10 & 0.09 & 0.13 \\
\hline FastSpin Conventional & 0.19 & 0.13 & 0.03 & 0.18 & 0.15 & 0.09 & 0.16 \\
\hline FastSpin Alternative & 0.24 & 0.13 & 0.05 & 0.18 & 0.15 & 0.10 & 0.16 \\
\hline E.Z.N.A. Conventional & 0.05 & 0.12 & 0.06 & 0.18 & 0.15 & 0.25 & 0.10 \\
\hline E.Z.N.A. Alternative & 0.27 & 0.12 & 0.07 & 0.18 & 0.15 & 0.26 & 0.10 \\
\hline
\end{tabular}

${ }^{\dagger}$ UltraClean: UltraClean ${ }^{\mathrm{TM}}$ Soil DNA Isolation Kit; PowerSoil: PowerSoil ${ }^{\circledR}$ DNA Isolation Kit; FastSPIN: FastDNA ${ }^{\circledR}$ SPIN Kit for Soil; E.Z.N.A.: E.Z.N.A. ${ }^{\circledR}$ Soil DNA Isolation Kit. " Example of calculation: Yield of extraction criterion for soil (using Table 3): $0.09=8.21 /(8.21+5.59+6.76+3.78+17.70+23.29+$ $4.33+25.98)$.

ple of calculation in Table 6) followed by the calculation of $E_{j}$ and $D_{j}$ using Formulas 2 and 3, respectively (Table 6). Finally the weight of each criterion was calculated using Formula 4. All criteria weights for soil, SM and SMB are summarized in Table 7. It should be added that in some cases the decision maker is experienced enough to have his/her own (subjective) weights, which can be combined by the (objective) Entropy weights extracted from Equation (4). The mathematical framework for the latter combined weighting scheme can be found in [43]. Here it is assumed that the decision maker is inexperienced and/or conservative where he/she has an equal preference towards the performance criteria and hence prefers to purely rely on the Entropy weights.

\subsection{Selecting an Optimal DNA Extraction Method for Each Sample Type: The TOPSIS Method}

The obtained weights of criteria were incorporated into the TOPSIS technique (Formulas 5-9) to calculate an overall score for each DNA extraction method for soil, SM, and SMB (Tables 8-12). The final rakings of the extraction methods for different sample types are shown in Tables 10-12. Based on these results, the extraction methods were ranked as follows:

For soil (Table 10, descending order): PowerSoil Alternative $>$ FastSpin Alternative $>$ E.Z.N.A. Alternative $>$ UltraClean Conventional $>$ PowerSoil Conventional > UltraClean Alternative $>$ FastSpin Conventional $>$ E.Z.N.A. Conventional $>$ Bead-Beating $=$ Freeze-Thaw;

For SM (Table 11, descending order): PowerSoil Conventional $>$ UltraClean Conventional $>$ UltraClean Alternative $>$ PowerSoil Alternative $>$ FastSpin Alternative
$>$ FastSpin Conventional > E.Z.N.A. Conventional > E.Z.N.A. Alternative $>$ Bead-Beating $=$ Freeze-Thaw;

For SMB (Table 12, descending order): PowerSoil Conventional $>$ UltraClean Conventional $>$ PowerSoil Alternative $>$ UltraClean Alternative $>$ FastSpin Conventional $>$ FastSpin Alternative $>$ E.Z.N.A. Conventional $>$ E.Z.N.A. Alternative $>$ Bead-Beating $=$ Freeze-Thaw.

\section{DISCUSSION}

The selection of an appropriate method for extracting DNA from complex ecosystems such as soil has a critical impact on the composition and richness of detected microbial communities using culture-independent molecular microbiological methods, such as competitive PCR, real-time PCR, denaturing gradient gel electrophoresis (DGGE) and Next-Generation DNA Sequencing (NGS) technologies $[9,10,11,29]$. In addition, it has been demonstrated that the quality of extracted DNA can interfere with microarray hybridizations, yielding high background noise and false positives $[9,10,24,50]$. These arguments show the necessity for carefully selecting a suitable DNA extraction method for each given sample type and proposed downstream DNA-based analyses.

In the present study, we compared both the quantity and quality of DNA extracted from soil, SM and SMB mixtures using 10 different DNA extraction methods to be used subsequently for PCR analysis. The results showed that both the quantity (yield of extraction) and the quality (purity, degree of degradation, easiness of amplification) of the extracted DNA depended on the extraction method and the type of environmental sample (Table 3), which was in agreement with earlier observations reported in the literature $[9,10,14,32,33]$. Moreover, 
Table 6. Calculating the entropy of data (column-wise) for each decision criterion for soil.

\begin{tabular}{|c|c|c|c|c|c|c|c|}
\hline \multirow{3}{*}{ Methods $^{\dagger}$} & \multicolumn{7}{|c|}{$p_{i j} \times \ln p_{i j}$} \\
\hline & $C_{1}$ & $C_{2}$ & $C_{3}$ & $C_{4}$ & $C_{5}$ & $C_{6}$ & $C_{7}$ \\
\hline & $\begin{array}{l}\text { Yield of } \\
\text { extraction }\end{array}$ & $\begin{array}{l}\mathrm{A}_{260 / 280} \\
\text { ratio }\end{array}$ & $\begin{array}{l}\mathrm{A}_{260 / 230} \\
\text { ratio }\end{array}$ & $\begin{array}{c}\text { Degree of DNA } \\
\text { degradation }\end{array}$ & $\begin{array}{c}\text { Easiness of } \\
\text { amplification }\end{array}$ & $\begin{array}{l}\text { Duration of } \\
\text { extraction }\end{array}$ & $\begin{array}{l}\text { Cost per } \\
\text { extraction }\end{array}$ \\
\hline UltraClean Conventional & $-0.21^{\ddagger}$ & -0.27 & -0.31 & -0.25 & -0.23 & -0.18 & -0.24 \\
\hline UltraClean Alternative & -0.17 & -0.26 & -0.30 & -0.17 & -0.23 & -0.19 & -0.24 \\
\hline PowerSoil Conventional & -0.19 & -0.26 & -0.30 & -0.17 & -0.23 & -0.20 & -0.27 \\
\hline PowerSoil Alternative & -0.13 & -0.26 & -0.36 & -0.17 & -0.23 & -0.21 & -0.27 \\
\hline Fast Spin Conventional & -0.31 & -0.26 & -0.11 & -0.31 & -0.28 & -0.22 & -0.29 \\
\hline Fast Spin Alternative & -0.34 & -0.26 & -0.14 & -0.31 & -0.28 & -0.23 & -0.29 \\
\hline E.Z.N.A. Conventional & -0.14 & -0.26 & -0.16 & -0.31 & -0.28 & -0.35 & -0.23 \\
\hline E.Z.N.A. Alternative & -0.35 & -0.25 & -0.19 & -0.31 & -0.28 & -0.35 & -0.23 \\
\hline Sum & -1.84 & -2.08 & -1.87 & -1.98 & -2.06 & -1.92 & -2.07 \\
\hline$E_{j}^{\S}$ & $0.89^{\pi}$ & 1.00 & 0.90 & 0.95 & 0.99 & 0.92 & 0.99 \\
\hline$D_{j}^{\#}$ & $0.11^{\dagger \dagger}$ & 0.00 & 0.10 & 0.05 & 0.01 & 0.08 & 0.01 \\
\hline
\end{tabular}

${ }^{\dagger}$ UltraClean: UltraClean ${ }^{\mathrm{TM}}$ Soil DNA Isolation Kit; PowerSoil: PowerSoil ${ }^{\circledR}$ DNA Isolation Kit; FastSPIN: FastDNA ${ }^{\circledR}$ SPIN Kit for Soil; E.Z.N.A.: E.Z.N.A. ${ }^{\circledR}$ Soil DNA Isolation Kit. "Example of calculation: $p_{11} \times \ln p_{11}$ (using Table 5, Formula 1) $=0.09 \times \ln (0.09) .{ }^{\S} E_{j}=$ entropy of the set of normalized data. "Example of calculation of $E_{1}$ where $\alpha=0.48$ (Formula 2): $\left.0.65=-0.48 \times[(-0.21)+(-0.17)+(-0.19))+(-0.13)+(-0.31)+(-0.34)\right] .{ }^{\#} D_{j}=$ degree of diversity. "ँExample of calculation of $D_{1}: 0.35=1-0.65$ (Formula 3).

Table 7. Criteria weights $\left(W_{j, j}=1,2, \cdots, 7\right)$ for soil, SM [soil:manure, 99:1(w/w)] and SMB [soil:manure:biochar, 98:1:1(w/w)].

\begin{tabular}{ccccccccc}
\hline & $C_{1}$ & $C_{2}$ & $C_{3}$ & $C_{4}$ & $C_{5}$ & $C_{6}$ & $C_{7}$ \\
\hline Soil & $0.32^{\dagger}$ & 0.00 & 0.28 & 0.14 & 0.03 & 0.21 & 0.02 \\
SM & 0.16 & 0.01 & 0.25 & 0.21 & 0.04 & 0.31 & 0.03 \\
SMB & 0.16 & 0.01 & 0.22 & 0.22 & 0.04 & 0.33 & 0.03 \\
\hline
\end{tabular}

'Example of calculation of $W_{1}$ (weight of yield of extraction for soil, formula 4), using $D_{1}$ in Table 6: $0.32=0.11 /(0.11+0.00+0.10+0.05+0.01+0.08$ $+0.01)$.

Table 8. Summary of normalized decision matrix data for TOPSIS method using seven decision criteria for each DNA extraction method for soil.

\begin{tabular}{cccccccc}
\hline & \multicolumn{9}{c}{ Normalized Decision Matrix Data } \\
\cline { 2 - 8 } Methods $^{\dagger}$ & $C_{1}$ & $C_{2}$ & $C_{3}$ & $C_{4}$ & $C_{5}$ & $C_{6}$ & $C_{7}$ \\
\cline { 2 - 8 } & $\begin{array}{c}\text { Yield of } \\
\text { extraction }\end{array}$ & $\mathrm{A}_{260 / 280}$ ratio & $\mathrm{A}_{260 / 230}$ ratio & $\begin{array}{c}\text { Degree of DNA } \\
\text { degradation }\end{array}$ & $\begin{array}{c}\text { Easiness of } \\
\text { amplification }\end{array}$ & $\begin{array}{c}\text { Duration of } \\
\text { extraction }\end{array}$ & $\begin{array}{c}\text { Cost per } \\
\text { extraction }\end{array}$ \\
\hline UltraClean Conventional & $0.20^{\ddagger}$ & 0.37 & 0.42 & 0.30 & 0.28 & 0.16 & 0.31 \\
UltraClean Alternative & 0.14 & 0.34 & 0.39 & 0.15 & 0.28 & 0.18 & 0.31 \\
PowerSoil Conventional & 0.16 & 0.35 & 0.41 & 0.15 & 0.28 & 0.19 & 0.37 \\
PowerSoil Alternative & 0.09 & 0.37 & 0.66 & 0.15 & 0.28 & 0.21 & 0.37 \\
FastSpin Conventional & 0.43 & 0.36 & 0.08 & 0.46 & 0.42 & 0.22 & 0.43 \\
FastSpin Alternative & 0.56 & 0.36 & 0.11 & 0.46 & 0.42 & 0.24 & 0.43 \\
E.Z.N.A. Conventional & 0.10 & 0.35 & 0.14 & 0.46 & 0.42 & 0.61 & 0.29 \\
E.Z.N.A. Alternative & 0.63 & 0.33 & 0.17 & 0.46 & 0.42 & 0.62 & 0.29 \\
\hline
\end{tabular}

${ }^{\dagger}$ UltraClean: UltraClean ${ }^{\mathrm{TM}}$ Soil DNA Isolation Kit; PowerSoil: PowerSoil ${ }^{\circledR}$ DNA Isolation Kit; FastSPIN: FastDNA ${ }^{\circledR}$ SPIN Kit for Soil; E.Z.N.A.: E.Z.N.A. ${ }^{\circledR}$ Soil DNA Isolation Kit. "Example of calculation: Yield of extraction criterion for soil (using Table 3): $0.20=8.21 /\left[(8.21)^{2}+(5.59)^{2}+(6.76)^{2}+(3.78)^{2}+\right.$ $\left.(17.70)^{2}+(23.29)^{2}+(4.33)^{2}+(25.98)^{2}+(5.24)^{2}+(5.49)^{2}\right]^{0.5}$. 
Table 9. Summary of the weighted normalized decision matrix data for the TOPSIS method using seven decision criteria for each DNA extraction method for soil.

\begin{tabular}{|c|c|c|c|c|c|c|c|}
\hline \multirow{3}{*}{ Methods $^{\dagger}$} & \multicolumn{7}{|c|}{ Vij } \\
\hline & $C_{1}$ & $C_{2}$ & $C_{3}$ & $C_{4}$ & $C_{5}$ & $C_{6}$ & $C_{7}$ \\
\hline & $\begin{array}{l}\text { Yield of } \\
\text { extraction }\end{array}$ & $\mathrm{A}_{260 / 280}$ ratio & $\mathrm{A}_{260 / 230}$ ratio & $\begin{array}{c}\text { Degree of DNA } \\
\text { degradation }\end{array}$ & $\begin{array}{l}\text { Easiness of } \\
\text { amplification }\end{array}$ & $\begin{array}{l}\text { Duration of } \\
\text { extraction }\end{array}$ & $\begin{array}{l}\text { Cost per } \\
\text { extraction }\end{array}$ \\
\hline UltraClean Conventional & $0.06^{\ddagger}$ & 0.00 & 0.12 & 0.04 & 0.01 & 0.03 & 0.01 \\
\hline UltraClean Alternative & 0.04 & 0.00 & 0.11 & 0.02 & 0.01 & 0.04 & 0.01 \\
\hline PowerSoil Conventional & 0.05 & 0.00 & 0.11 & 0.02 & 0.01 & 0.04 & 0.01 \\
\hline PowerSoil Alternative & 0.03 & 0.00 & 0.19 & 0.02 & 0.01 & 0.04 & 0.01 \\
\hline FastSpin Conventional & 0.14 & 0.00 & 0.02 & 0.06 & 0.01 & 0.05 & 0.01 \\
\hline FastSpin Alternative & 0.18 & 0.00 & 0.03 & 0.06 & 0.01 & 0.05 & 0.01 \\
\hline E.Z.N.A. Conventional & 0.03 & 0.00 & 0.04 & 0.06 & 0.01 & 0.13 & 0.01 \\
\hline E.Z.N.A. Alternative & 0.20 & 0.00 & 0.05 & 0.06 & 0.01 & 0.13 & 0.01 \\
\hline Sum & 0.74 & 0.00 & 0.67 & 0.36 & 0.08 & 0.51 & 0.06 \\
\hline $\mathrm{V}+\S$ & 0.20 & 0.00 & 0.19 & 0.06 & 0.01 & 0.13 & 0.01 \\
\hline V- ${ }^{\circledR}$ & 0.03 & 0.00 & 0.02 & 0.02 & 0.01 & 0.03 & 0.01 \\
\hline
\end{tabular}

'UltraClean: UltraClean ${ }^{\mathrm{TM}}$ Soil DNA Isolation Kit; PowerSoil: PowerSoil ${ }^{\circledR}$ DNA Isolation Kit; FastSPIN: FastDNA ${ }^{\circledR}$ SPIN Kit for Soil; E.Z.N.A.: E.Z.N.A. ${ }^{\circledR}$ Soil DNA Isolation Kit. "Example of calculation: $0.06=0.20$ (normalized data for UltraClean Conventional under the yield of extraction criterion, Table 8) $\times$ 0.32 (weight of yield of extraction criterion for soil, Table 7). ${ }^{\S}$ Ideal positive solution. "Ideal negative solution.

Table 10. Summary of the positive and negative distances and the final TOPSIS scores of DNA extractions methods for soil.

\begin{tabular}{ccccc}
\hline \multirow{2}{*}{ Methods $^{\dagger}$} & $d_{i}^{+}$ & \multicolumn{2}{c}{$d_{i}^{-}$} & TOPSIS Score $: C_{i}+$ Rank \\
\cline { 2 - 5 } & Value & Value & Value & \\
\hline UltraClean Conventional & $0.156^{\ddagger}$ & $0.140^{\S}$ & $0.474^{\uparrow}$ & 4 \\
UltraClean Alternative & 0.175 & 0.134 & 0.433 & 6 \\
PowerSoil Conventional & 0.165 & 0.136 & 0.452 & 5 \\
PowerSoil Alternative & 0.172 & 0.189 & 0.522 & 1 \\
FastSpin Conventional & 0.181 & 0.136 & 0.429 & 7 \\
FastSpin Alternative & 0.164 & 0.171 & 0.511 & 2 \\
E.Z.N.A. Conventional & 0.247 & 0.018 & 0.068 & 8 \\
E.Z.N.A. Alternative & 0.176 & 0.174 & 0.496 & 3 \\
\hline
\end{tabular}

${ }^{\dagger}$ UltraClean: UltraClean ${ }^{\mathrm{TM}}$ Soil DNA Isolation Kit; PowerSoil: PowerSoil ${ }^{\circledR}$ DNA Isolation Kit; FastSPIN: FastDNA ${ }^{\circledR}$ SPIN Kit for Soil; E.Z.N.A.: E.Z.N.A. ${ }^{\circledR}$ Soil DNA Isolation Kit. Example of calculation ${ }^{\star}$ using Table 9: $0.156=(0.06-0.20)^{2}+(0.00-0.00)^{2}+(0.12-0.19)^{2}+(0.04-0.06)^{2}+$ $(0.01-0.01)^{2}+(0.03-0.013)^{2}+(0.01-0.01)^{2} ;{ }^{\S_{0}} 0.140=(0.06-0.03)^{2}+$ $(0.00-0.00)^{2}+(0.12-0.02)^{2}+(0.04-0.02)^{2}+(0.01-0.01)^{2}+(0.03-$ $0.03)^{2}+(0.01-0.01)^{0.5} ;{ }^{9} 0.474=0.140 /(0.140+0.156)$.

the application of an alternative lysis step for most of the extraction methods did not improve their performance significantly, except for the E.Z.N.A. method (Table 3). This method, both its conventional and alternative versions, resulted in high values of DNA purity. However, the E.Z.N.A. conventional method provided much lower yields of extraction in comparison to its alternative method, as was also observed in other investigations [32,33].

Because of the demonstrated conflicts among different
Table 11. Summary of the positive and negative distances and the final TOPSIS scores of DNA extractions methods for SM [soil:manure, 99:1(w/w)].

\begin{tabular}{ccccc}
\hline \multirow{2}{*}{ Methods $^{\dagger}$} & \multicolumn{1}{c}{$d_{i}^{+}$} & \multicolumn{2}{c}{$d_{i}^{-}$TOPSIS Score $: C_{i}+$ Rank } \\
\cline { 2 - 5 } & Value & Value & Value & \\
\hline UltraClean Conventional & 0.056 & 0.176 & 0.757 & 2 \\
UltraClean Alternative & 0.087 & 0.160 & 0.647 & 3 \\
PowerSoil Conventional & 0.055 & 0.184 & 0.770 & 1 \\
PowerSoil Alternative & 0.086 & 0.153 & 0.640 & 4 \\
FastSpin Conventional & 0.125 & 0.138 & 0.524 & 6 \\
FastSpin Alternative & 0.119 & 0.133 & 0.529 & 5 \\
E.Z.N.A. Conventional & 0.168 & 0.095 & 0.362 & 7 \\
E.Z.N.A. Alternative & 0.183 & 0.067 & 0.268 & 8 \\
\hline
\end{tabular}

${ }^{\dagger}$ UltraClean: UltraClean ${ }^{\mathrm{TM}}$ Soil DNA Isolation Kit; PowerSoil: PowerSoil ${ }^{\mathbb{R}}$ DNA Isolation Kit; FastSPIN: FastDNA ${ }^{\circledR}$ SPIN Kit for Soil; E.Z.N.A.: E.Z.N.A. ${ }^{\circledR}$ Soil DNA Isolation Kit.

extraction methods and criteria, the selection of the optimum method for different types of soil was not straightforward (Table 4). For this reason, for the first time in the field, the application of a systematic MCDM approach was proposed and implemented to select overall the optimum DNA extraction method for each type of soil. The PowerSoil method was systematically defined as the best performing method for extracting DNA from soil samples; more specifically, for soil, the alternative version of the PowerSoil method gained the first rank (Table 10), while for SM and SMB its conventional ver- 
Table 12. Summary of the positive and negative distances and the final TOPSIS scores of DNA extraction methods for SMB [soil:manure:biochar, 98:1:1(w/w)].

\begin{tabular}{ccclc}
\hline \multirow{2}{*}{ Methods ${ }^{\dagger}$} & \multicolumn{1}{c}{$d_{i}^{+}$} & $d_{i}^{-}$ & TOPSIS Score : $C_{i}+$ Rank \\
\cline { 2 - 5 } & Value & Value & Value & \\
\hline UltraClean Conventional & 0.065 & 0.162 & 0.714 & 2 \\
UltraClean Alternative & 0.080 & 0.160 & 0.666 & 4 \\
PowerSoil Conventional & 0.059 & 0.172 & 0.744 & 1 \\
PowerSoil Alternative & 0.072 & 0.153 & 0.681 & 3 \\
FastSpin Conventional & 0.108 & 0.141 & 0.567 & 5 \\
FastSpin Alternative & 0.116 & 0.132 & 0.531 & 6 \\
E.Z.N.A. Conventional & 0.176 & 0.088 & 0.333 & 7 \\
E.Z.N.A. Alternative & 0.193 & 0.030 & 0.134 & 8 \\
\hline
\end{tabular}

${ }^{\dagger}$ UltraClean: UltraClean ${ }^{\mathrm{TM}}$ Soil DNA Isolation Kit; PowerSoil: PowerSoil ${ }^{\circledR}$ DNA Isolation Kit; FastSPIN: FastDNA ${ }^{\circledR}$ SPIN Kit for Soil; E.Z.N.A.: E.Z.N.A. ${ }^{\circledR}$ Soil DNA Isolation Kit.

sion performed best (Tables 11 and 12, respectively).

The performances of the DNA extraction kits assessed in the present study (Table 3) were similar or better than those reported in the literature. For the PowerSoil kit, which ranked first in the present work, the yields of extraction ranged between 3.78 and $11.97 \mu \mathrm{g}$ of DNA/g of soil, while the $\mathrm{A}_{260 / 280}$ and $\mathrm{A}_{260 / 230}$ ratios varied from 1.55 to 1.96 and 0.86 to 2.07 , respectively. Previous studies reported yields of extraction of 0.12 to $23.0 \mu \mathrm{g}$ of DNA/g of soil, as well as $\mathrm{A}_{260 / 280}$ and $\mathrm{A}_{260 / 230}$ ratios of 1.34 - 1.65 and $0.55-0.61$, respectively $[10,14,32,33]$.

Using the UltraClean kit, we obtained yields of extraction ranging from 5.59 to $14.21 \mu \mathrm{g}$ of DNA/g of soil, $\mathrm{A}_{260 / 280}$ ratios between 1.50 and 1.77, and $\mathrm{A}_{260 / 230}$ ratios between 0.81 and 1.43. Other authors presented yields of extraction between 0.31 and $2.81 \mu \mathrm{g}$ of $\mathrm{DNA} / \mathrm{g}$ of soil, an average $\mathrm{A}_{260 / 280}$ ratio of 1.33 , and $\mathrm{A}_{260 / 230}$ ratios between 0.67 and 2.20 [10,29,31,34].

In the present study, the yields of extraction with the FastSpin kit ranged between 17.70 and $23.87 \mu \mathrm{g}$ of DNA/g of soil, whereas the $A_{260 / 280}$ and $A_{260 / 230}$ ratios were $1.70-1.84$ and $0.25-0.60$, respectively. The literature indicates lower yields of extraction ( 0.80 to 9.12 $\mu \mathrm{g}$ of DNA/g of soil), $\mathrm{A}_{260 / 280}$ ratios (1.53 to 1.64) and $\mathrm{A}_{260 / 230}$ ratios (0.24 to 0.28$)$ [10,29-31,33].

Regarding the E.Z.N.A. kit, Table 3 indicates yields of extraction of 4.33 to $25.98 \mu \mathrm{g}$ of DNA/g of soil (with significant improvements using the alternative method), $\mathrm{A}_{260 / 280}$ ratios of 1.56 to 1.87 , and $\mathrm{A}_{260 / 230}$ ratios of 0.30 to 1.70. Previous publications included similar or lower yields of extraction (between 0.60 to $12.5 \mu \mathrm{g}$ of DNA/g of soil), similar $\mathrm{A}_{260 / 280}$ ratios ranging from 1.75 to 1.87, and generally higher $\mathrm{A}_{260 / 230}$ ratios varying from 1.59 to $1.87[32,33]$.

\section{CONCLUDING REMARK}

In summary, the choice of a DNA extraction method for microbial ecology studies is critical to obtain reliable results since each method can affect the composition and the richness of microbial communities of tested samples. Hence, in selecting a suitable extraction method, it is necessary to take into account the type of the environmental sample (in our case, soil, SM, and SMB), quantitative and qualitative characteristics of extracted DNA (e.g., yield of extraction, purity, degradation degree, quality of PCR products), and downstream molecular analyses such as competitive PCR, real-time PCR, denaturing gradient gel electrophoresis (DGGE) and large-scale parallel-pyrosequencing. Based on the results of the performed case study, overall we recommend the PowerSoil ${ }^{\circledR}$ DNA Isolation Kit as an optimum method for obtaining total bacterial DNA from soil and soil-containing mixtures such as soil:manure and soil:manure:biochar. The standardization/selection of DNA extraction techniques in the field is a current problem, and hence the powerful MCDM approaches such as entropy/TOPSIS which were used in this study are recommended as a first step towards comparing similar methods in other studies.

\section{ACKNOWLEDGEMENTS}

This work was supported by the National Sciences and Engineering Research Council of Canada (NSERC-Discovery Grant) and the Fonds de recherche du Quebec sur la Nature et les Technologies (FRQNT-Team Research Grant Project) for operating funds, and by the Canada Foundation for Innovation (CFI-Leaders Opportunity Fund) for infrastructure funds to Martin R. Chénier. Snizhana V. Olishevska benefited from the CFI-Infrastructure Operating Fund for personal support. The financial support by UBC's Work-Study Program to Sepideh Pakpour is also greatly acknowledged.

\section{REFERENCES}

[1] Robe, P., Nalin, R., Capellano, C., Vogel, T.A. and Simonet, P. (2003) Extraction of DNA from soil. European Journal of Soil Biology, 39, 183-190. http://dx.doi.org/10.1016/S1164-5563(03)00033-5

[2] Verheijen, F.G.A., Jeffery, S., Bastos, A.C., van der Velde, M. and Diafas, I. (2009) Biochar application to soils a critical scientific review of fffects on soil properties, processes and functions. EUR $24099 \mathrm{EN}$, Office for the Official Publications of the European Communities, Luxembourg.

[3] Amann, R.I., Ludwig, W. and Schleifer, K.H. (1995) Phylogenetic identification and in situ detection of individual microbial cells without cultivation. Microbiology Reviews, 59, 143-169.

[4] Roose-Amsaleg, C.L., Garnier-Sillam, E. and Harry, M. (2001) Extraction and purification of microbial DNA from soil and sediment samples. Applied Soil Ecology, 18, 
47-60. http://dx.doi.org/10.1016/S0929-1393(01)00149-4

[5] Torsvik, V., Goksoyr, J. and Daae, F.L. (1990) High diversity in DNA of soil bacteria. Applied and Environmental Microbiology, 56, 782-787.

[6] Ritz, K. (2007) The plate debate: Cultivable communities have no utility in contemporary environmental microbial ecology. Fems Microbiology Ecology, 60, 358-362. http://dx.doi.org/10.1111/j.1574-6941.2007.00331.x

[7] Morris, C.E., Bardin, M., Berge, O., Frey-klett, P., Fromin, N., Girardin, H., Guinebretiére, M.H., Lebaron, P., Thiéry, J.M. and Trousselier, M. (2002) Microbial biodiversity: Approaches to experimental design and hypothesis testing in primary scientific literature from 1975 to 1999. Microbiology and Molecular Biology Reviews, 66, 592-616.

http://dx.doi.org/10.1128/MMBR.66.4.592-616.2002

[8] Dorigo, U., Volatier, L. and Humbert, J.F. (2005) Molecular approaches to the assessment of biodiversity in aquatic microbial communities. Water Research, 39, 22072218. http://dx.doi.org/10.1016/j.watres.2005.04.007

[9] De Lipthay, J.R., Enzinger, C., Johnsen, K., Aamand, J., and Sorensen, S.J. (2004) Impact of DNA extraction method on bacterial community composition measured by denaturing gradient gel electrophoresis. Soil Biology \& Biochemistry, 36, 1607-1614. http://dx.doi.org/10.1016/j.soilbio.2004.03.011

[10] Ning, J., Liebich, J., Kastner, M., Zhou, J.Z., Schaffer, A. and Burauel, P. (2009) Different influences of DNA purity indices and quantity on PCR-based DGGE and functional gene microarray in soil microbial community study. Applied Microbiology and Biotechnology, 82, 983-993. http://dx.doi.org/10.1007/s00253-009-1912-0

[11] Carrigg, C., Rice, O., Kavanagh, S., Collins, G. and O'Flaherty, V. (2007) DNA extraction method affects microbial community profiles from soils and sediment. Applied Microbiology and Biotechnology, 77, 955-964. http://dx.doi.org/10.1007/s00253-007-1219-y

[12] Roh, C., Villatte, F., Kim, B.G. and Schmid, R.D. (2006) Comparative study of methods for extraction and purification of environmental DNA from soil and sludge samples. Applied Biochemistry and Biotechnology, 134, 97-112. http://dx.doi.org/10.1385/ABAB:134:2:97

[13] Arbeli, Z. and Fuentes, C.L. (2007) Improved purification and PCR amplification of DNA from environmental samples. Fems Microbiology Letters, 272, 269-275. http://dx.doi.org/10.1111/j.1574-6968.2007.00764.x

[14] Rosa, M.M., Tornisielo, S.M.T. and Ceccato-Antonini, R. (2010) Evaluation of different techniques for DNA direct extraction from Brazilian agricultural soil. HOLOS Environment, 10, 12-25.

[15] Burgmann, H., Pesaro, M., Widmer, F. and Zeyer, J. (2001) A strategy for optimizing quality and quantity of DNA extracted from soil. Journal of Microbiological Methods, 45, 7-20. http://dx.doi.org/10.1007/s11104-007-9193-9

[16] Steiner, C., Teixeira, W.G., Lehmann, J., Nehls, T., de Macedo, J.L.V., Blum, W.E.H. and Zech, W. (2007) Long term effects of manure, charcoal and mineral fer- tilization on crop production and fertility on a highly weathered Central Amazonian upland soil. Plant and Soil, 291, 275-290. http://dx.doi.org/10.1007/s11104-007-9193-9

[17] Mathews, J.A. (2008) Carbon-negative biofuels. Energy Policy, 36, 940-945. http://dx.doi.org/10.1016/j.enpol.2007.11.029

[18] Laird, D.A. (2008) The charcoal vision: A win-win-win scenario for simultaneously producing bioenergy, permanently sequestering carbon, while improving soil and water quality. Agronomy Journal, 100, 178-181. http://dx.doi.org/10.2134/agrojnl2007.0161

[19] Sohi, S., Loez-Capel, E., Krull, E. and Bol, R. (2009) Biochar's roles in soil and climate change: A review of research needs. Okehampton, UK.

[20] Tebbe, C.C. and Vahjen, W. (1993) Interference of humic acids and DNA extracted directly from soil in detection and transformation of recombinant-DNA from bacteria and a yeast. Applied and Environmental Microbiology, 59, 2657-2665.

[21] Sørensen, S.J., Müller, A.K., Hansen, L.H., Rasmussen, L.D., Lipthay, J.R. and Barkay, T. (2002) Molecular methods for assessing and manipulating the diversity of microbiological populations and processes. In: Burns RG, Dick RP, Eds., Enzymes in the Environment, Marcel Dekker, New York. http://dx.doi.org/10.1201/9780203904039.ch14

[22] Fortin, N., Beaumier, D., Lee, K. and Greer, C.W. (2004) Soil washing improves the recovery of total community DNA from polluted and high organic content sediments. Journal of Microbiological Methods, 56, 181-191. http://dx.doi.org/10.1016/j.mimet.2003.10.006

[23] Wu, L.Y., Thompson, D.K., Li, G.S., Hurt, R.A., Tiedje, J.M. and Zhou, J. (2001) Development and evaluation of functional gene arrays for detection of selected genes in the environmental. Applied and Environmental Microbiology, 67, 5780-5790.

http://dx.doi.org/10.1128/AEM.67.12.5780-5790.2001

[24] Zhou, J.Z. and Thompson, D.K. (2002) Challenges in applying microarrays to environmental studies. Current Opinion in Biotechnology, 13, 204-207. http://dx.doi.org/10.1016/S0958-1669(02)00319-1

[25] Holben, W.E., Jansson, J.K., Chelm, B.K. and Tiedje, J.M. (1988) DNA probe method for the detection of specific microorganisms in the soil bacterial community. Applied and Environmental Microbiology, 54, 703-711.

[26] Jacobsen, C.S. and Rasmussen, O.F. (1992) Development and application of a new method to extract bacterialDNA from soil based on separation of bacteria from soil with cation-exchange resin. Applied and Environmental Microbiology, 58, 2458-2462.

[27] Yeates, C., Gillings, M.R., Davison, A.D., Altavilla, N. and Veal, D.A. (1998) Methods for microbial DNA extraction from soil for PCR amplification. Biological Procedures Online, 14, 1-8. http://dx.doi.org/10.1251/bpo6

[28] Kumar, P.P. (2011) An improved method for extraction of heterologous DNA from environmental samples for the construction of metagenomic libreries. International Journal of Pharma and Bio Sciences, 2, 368-373. 
[29] Martin-Laurent, F., Philippot, L., Hallet, S., Chaussod, R., Germon, J.C., Soulas, G., and Catroux, G. (2001) DNA extraction from soils: Old bias for new microbial diversity analysis methods. Applied and Environmental Microbiology, 67, 2354-2359. http://dx.doi.org/10.1128/AEM.67.5.2354-2359.2001

[30] Park, J.W. and Crowley, D.E. (2005) Normalization of soil DNA extraction for accurate quantification real-time PCR and of target genes by DGGE. Biotechniques, 38, 579-586. http://dx.doi.org/10.2144/05384ST04

[31] Klerks, M.M., van Bruggen, A.H.C, Zijlstra, C. and Donnikov, M. (2006) Comparison of methods of extracting Salmonella enterica serovar enteritidis DNA from Model Based on Aras-G and AHP Methods for Multiple environmental substrates and quantification of organisms by using a general internal procedural control. Applied and Environmental Microbiology, 72, 3879-3886. http://dx.doi.org/10.1128/AEM.02266-05

[32] Huang, B., Zu, T. and Guo, Q. (2007) Extract PCR-ready soil DNA with the new E.Z.N.A. ${ }^{\circledR}$ soil DNA isolation kit. The Market Source for Life Science VWR biomarker International, 26-27.

[33] Dineen, S.M., Aranda, R., Anders, D.L., and Robertson, J.M. (2010) An evaluation of commercial DNA extraction kits for the isolation of bacterial spore DNA from soil. Journal of Applied Microbiology, 109, 1886-1896. http://dx.doi.org/10.1111/j.1365-2672.2010.04816.x

[34] Fitzpatrick, K.A., Kersh, G.J. and Massung, R.F. (2010) Practical Method for Extraction of PCR-Quality DNA from Environmental Soil Samples. Applied and Environmental Microbiology, 76, 4571-4573. http://dx.doi.org/10.1128/AEM.02825-09

[35] Roy, B. (1993) Aide Multicritère à la Décision: Méthodes et Cas. Economica, Paris.

[36] Roy, B. (1990) Decision-aid and decision-making. In: Bana, E. and Costa, C.A., Eds., Readings in Multiple Criteria Decision-Aid. Springer-Verlag, Heidelberg, 17-35. http://dx.doi.org/10.1007/978-3-642-75935-2_ 2

[37] Collette, Y. and Siarry, P. (2003) Multiobjective optimization. Springer-Verlag, New York.

[38] Pakpour, S., Milani, A. and Chénier, M. (2012) A multicriteria decision-making approach for comparing sample preservation and DNA extraction methods from swine feces. American Journal of Molecular Biology, 2, 159169. http://dx.doi.org/10.4236/ajmb.2012.22018

[39] Putrus, P. (1990) Accounting for intangibles in integrated manufacturing-nonfinancial justification based on the analytical hierarchy process. Information Strategy, 6, 2530.

[40] Boucher, T.O. and McStravic, E.L. (1991) Multi-attribute evaluation within a present value framework and its relation to the analytic hierarchy process. The Engineering Economist, 37, 55-71. http://dx.doi.org/10.1080/00137919108903055

[41] Pohekar, S.D. and Ramachandran, M. (2004) Application of multi-criteria decision making to sustainable energy planning-A review. Renewable and Sustainable Energy Reviews, 8, 365-381. http://dx.doi.org/10.1016/i.rser.2003.12.007

[42] Turskis, Z., Zavadskas, K.E. and Kutut, V. (2013) A criteria prioritizing of heritage value. International Journal of Information Technology and Decision Making, 12, 45. http://dx.doi.org/10.1142/S021962201350003X

[43] Hwang, C.L. and Yoon, K. (1981) Multiple attribute decision making: Methods and applications. Springer-Verlag, New York. http://dx.doi.org/10.1007/978-3-642-48318-9

[44] Ewa, R. (2011) Multi-criteria decision making models by applying the TOPSIS method to crisp and interval data. In: Trzaskalik, T. and Wachowicz, T., Eds., Multiple Criteria Decision Making, The University of Economics, Katowice, pp. 200-230.

[45] Muyzer, G., Dewaal, E.C. and Uitterlinden, A.G. (1993) Profiling of complex microbial-populations by denaturing gradient gel-electrophoresis analysis of polymerase chain reaction-amplified genes-coding for 16s ribosomal-RNA. Applied and Environmental Microbiology, 59, 695-700.

[46] Chenier, M.R. and Juteau, P. (2009) Fate of chlortetracycline- and tylosin-resistant bacteria in an aerobic thermophilic sequencing batch reactor treating swine waste. Microbial Ecology, 58, 86-97. http://dx.doi.org/10.1007/s00248-008-9478-4

[47] Thermo Fisher Scientific (2009) NanoDrop 2000/2000c spectrophotometer, V1.0 user manual.

[48] Ahn, B.S. (2011) Compatible weighting method with rank order centroid: Maximum entropy ordered weighted averaging approach. European Journal of Operational Research, 212, 552-559. http://dx.doi.org/10.1016/j.ejor.2011.02.017

[49] Zou, Z.H., Yan, Y. and Sun, J.N. (2006) Entropy method for determination of weight of evaluating indicators in fuzzy synthetic evaluation for water quality assessment. Journal of Environmental Sciences-China, 18, 1020-1023. http://dx.doi.org/10.1016/S1001-0742(06)60032-6

[50] Lemarchand, K., Berthiaume, F., Maynard, C., Harel, J., Payment, P., Bayardelle, P., Masson, L. and Brousseau, R. (2005) Optimization of microbial DNA extraction and purification from raw wastewater samples for downstream pathogen detection by microarrays. Journal of Microbiological Methods, 63, 115-126. http://dx.doi.org/10.1016/j.mimet.2005.02.021 